\title{
D-1 Type of Dopamine Autoreceptors Are Not Involved in the Regulation of Dopamine Synthesis in the Striatum
}

\author{
Hiroshi WATANABE, Hiroshi SUDA, Shun-ichi SEKIHARA \\ and Yasuyuki NOMURA \\ Research Institute for Wakan-Yaku, Toyama Medical and Pharmaceutical University, \\ Toyama 930-01, Japan \\ Accepted December 24, 1986
}

\begin{abstract}
To clarify if dopamine (DA) synthesis is regulated by D-1 DA receptors located on dopaminergic nerve terminals in the striatum, we investigated effects of D-1 DA receptor agonist and antagonist on striatal 3,4-dihydroxyphenylalanine (DOPA) accumulation induced by $r$-butyrolactone in mice treated with an amino acid decarboxylase inhibitor. SKF 38393, a D-1 agonist, did not affect DOPA accumulation, whereas apomorphine that stimulates both D-1 and D-2 receptors inhibited the accumulation. SCH 23390, a D-1 antagonist, did not antagonize apomorphine-induced inhibition of DOPA accumulation, while YM-09151-2, a D-2 antagonist, reversed it. These results suggest that D-1 type of DA autoreceptors is not involved in the inhibition of in vivo DA synthesis.
\end{abstract}

Selective stimulation of dopamine (DA) autoreceptors located on dopaminergic nerve terminals in the striatum modulates the release of DA in vitro $(1,2)$ and DA synthesis in vitro and in vivo (3-5). Electrical stimulation- or depolarization-induced release of ${ }^{3} \mathrm{H}-\mathrm{DA}$ is inhibited by treatment with apomorphine and a $D-2$ receptor agonist, $L Y$ 141865 , and this inhibition is antagonized by a D-2 receptor antagonist, (-)-sulpiride, while the release was not suppressed by the D-1 receptor agonist SKF $38393(6,7)$. These results suggest that release-inhibiting $D A$ autoreceptors can be classified as the D-2 type (linked or not linked to an inhibition of adenylate cyclase) (8).

It is not known, however, whether those receptors are identical to autoreceptors regulating DA synthesis in nerve endings, but recent data suggest that they are distinct because doses of apomorphine which inhibit the synthesis of DA have no effect on its release in striatal slices (3). Further, no data have been reported about whether the D-1 type of autoreceptors is involved in the regulation of DA synthesis or not. Hence, to clarify if DA synthesis in the striatum is regulated by a mediation of the D-1 type of
DA autoreceptors, we investigated effects of D-1 receptor agonist and antagonist on striatal 3,4-dihydroxyphenylalanine (DOPA) accumulation, which reflects DA synthesis, induced by $\gamma$-butyrolactone in mice treated with an amino acid decarboxylase inhibitor and compared them with those of D-2 receptor related agents.

Adult male albino mice weighing 22-30 g (ddY strain. Shizuoka Laboratory Animal Center, Shizuoka) were used. Mice were injected with SKF 38393 or apomorphine, $10 \mathrm{~min}$ later with $\gamma$-butyrolactone $(750 \mathrm{mg} /$ $\mathrm{kg}$, i.p.), and a further $5 \mathrm{~min}$ later with 3hydroxybenzylhydrazine $(100 \mathrm{mg} / \mathrm{kg}$, i.p.) to inhibit aromatic amino acid decarboxylase. Mice were killed by decapitation $30 \mathrm{~min}$ after the treatment with the decarboxylase inhibitor. The striata were dissected out after removal of the brain, homogenized in $1 \mathrm{ml}$ of $0.25 \mathrm{~N}$ perchloric acid containing $0.2 \mu \mathrm{M}$ EDTA and $40 \mathrm{ng}$ of 3.4-dihydroxybenzylamine as an internal standard. DOPA and catecholamines were extracted with alumina and assayed using HPLC with electrochemical detection (9,10).

Apomorphine hydrochloride (Dainippon Seiyaku), SKF 38393 (1 - phenyl-2,3,4,5-tetra- 
hydro-(1H)-3-benzazepine-7,8-diol hydrochloride: Research Biochemicals Inc.) and 3-hydroxybenzylhydrazine dihydrochloride (Sigma Chemical Co.) were dissolved in sterile saline containing $0.05 \%$ ascorbic acid. Haloperidal (Janssen), ( \pm )-sulpiride (Fujisawa Yakuhin), YM 09151-2 (cis-N-(1-benzyl-2methylpyrrolidin-3-yl) -5-chloro-2-methoxy4-methyl-aminobenzamide; Yamanouchi Seiyaku) and SCH 23390 (R-(+)-8-chloro2,3,4,5-tetrahydro-3-methyl-5-phenyl- $1 \mathrm{H}-3$ benzazepine-7-ol-maleate; Schering Corp.) were dissolved in saline containing $0.1 \%$ tartaric acid. $r$-Butyrolactone (Tokyo Kasei) was dissolved in physiological saline. All doses refer to the salt except for 3hydroxybenzylhydrazine. Data were analyzed using one-way analysis of variance with Duncan's multiple comparison test (11).

$r$-Butyrolactone $(750 \mathrm{mg} / \mathrm{kg}$, i.p.) produced a rise in striatal DOPA levels to nearly $200 \%$ above 3-hydroxybenzylhydrazine treated values. Pretreatment of animals with SKF 38393 (0.3-30 $\mathrm{mg} / \mathrm{kg}$. s.c.) caused no changes in DOPA accumulation induced by $\gamma$-butyrolactone. whereas apomorphine $(0.03$ $-0.3 \mathrm{mg} / \mathrm{kg}$, s.c.) inhibited it in a dosedependent manner (Table 1).

The inhibitory effect of apomorphine was not affected by pretreatment with SCH 23390 $(0.025-2.5 \mathrm{mg} / \mathrm{kg}$. s.c.). Whereas it was reversed by haloperidol $(0.05 \mathrm{mg} / \mathrm{kg}$, s.c.)
( \pm )-sulpiride $(100 \mathrm{mg} / \mathrm{kg}$, s.c.) and YM$09151-2$ (0.005 mg/kg, s.c.) (Table 2).

The previous findings that SKF 38393 affects neither DA disappearance following $\alpha$-methyl-p-tyrosine treatment (12) nor striatal DOPA levels after an amino acid decarboxylase inhibitor (13, 14) suggest that the D-1 type of auto- and/or postsynaptic DA receptors are not involved in the regulation of DA turnover and synthesis. The present results have shown that autoreceptors regulating $D A$ synthesis in the striatum are not stimulated by the D-1 receptor agonist SKF 38393 (15), while they are stimulated by apomorphine; the stimulatory effect of apomorphine is antagonized by $\mathrm{D}-2$ receptor antagonists, ( \pm )-sulpiride (8) and YM09151-2 (16), but not by a D-1 receptor antagonist $(17,18)$. It has been shown that DA synthesis in rat striatal slices which do not contain a striatonigral feedback loop is inhibited by apomorphine or the D-2 receptor agonist LY $141865(3,19)$, and this inhibition is antagonized by an addition of haloperidol in a superfusion system (3). In vivo DA synthesis increased by $\gamma$-butyrolactone is inhibited by D-2 receptor agonists, lisuride and bromocriptine, and the inhibition is antagonized by pretreatment with (-)sulpiride in the rat striatum (20). Thus, the present results support the neurochemical data suggesting that DA autoreceptors which

Table 1. Effects of SKF 38393 and apomorphine on DOPA accumulation induced by $r$-butyrolactone in the striatum of the mouse treated with an amino acid decarboxylase inhibitor

\begin{tabular}{|c|c|c|c|c|}
\hline Treatment & $\begin{array}{c}\text { Dose } \\
(\mathrm{mg} / \mathrm{kg})\end{array}$ & $N$ & $\begin{array}{c}\text { DOPA } \\
(\mu \mathrm{g} / \mathrm{g} \text { wet tissue })\end{array}$ & $\stackrel{\%}{\%}$ \\
\hline$\gamma$-Butyrolactone control & - & - & $4.99 \pm 0.16$ & $100^{--}$ \\
\hline SKF 38393 & $\begin{array}{r}0.3 \\
1.0 \\
3.0 \\
10.0 \\
30.0\end{array}$ & $\begin{array}{l}5 \\
5 \\
5 \\
5 \\
5\end{array}$ & $\begin{array}{l}4.82 \pm 0.31 \\
5.45 \pm 0.24 \\
5.70 \pm 0.39 \\
4.61 \pm 0.42 \\
4.96 \pm 0.39\end{array}$ & $\begin{array}{r}96.6 \\
109.2 \\
114.2 \\
92.4 \\
99.4\end{array}$ \\
\hline Apomorphine & $\begin{array}{l}0.03 \\
0.05 \\
0.1 \\
0.3\end{array}$ & $\begin{array}{l}5 \\
5 \\
5 \\
5\end{array}$ & $\begin{array}{l}4.67 \pm 0.27 \\
3.49 \pm 0.16^{* *} \\
2.36 \pm 0.30^{* *} \\
1.77 \pm 0.14^{* *}\end{array}$ & $\begin{array}{l}93.6 \\
76.0 \\
47.3 \\
37.9\end{array}$ \\
\hline
\end{tabular}

Each value represents the mean \pm S.E.M. DOPA levels after 3 -hydroxybenzylhydrazine treatment were $1.61 \pm 0.08 \mu \mathrm{g} / \mathrm{g}(N=12)$. $N=$ number of experiments. ${ }^{*} \mathrm{P}<0.01$, compared with the $\gamma$-butyrolactone control. 
Table 2. Effects of D-1 and D-2 receptor antagonists on apomorphine-induced decrease in striatal DOPA accumulation following the treatment with $\gamma$-butyrolactone plus 3 -hydroxybenzylhydrazine

\begin{tabular}{|c|c|c|c|c|}
\hline Treatment & $\begin{array}{c}\text { Dose } \\
(\mathrm{mg} / \mathrm{kg})\end{array}$ & $N$ & $\begin{array}{c}\text { DOPA } \\
(\mu \mathrm{g} / \mathrm{g} \text { wet tissue })\end{array}$ & $\begin{array}{c}\% \\
\text { of control }\end{array}$ \\
\hline$\overline{\gamma-B u t y r o l a c t o n e ~ c o n t r o l}$ & - & -- 12 & $4.44 \pm 0.14$ & 100 \\
\hline Apomorphine & 0.1 & 12 & $2.61 \pm 0.07^{* *}$ & 58.8 \\
\hline Apomorphine & 0.1 & & & \\
\hline$+\mathrm{SCH} 23390$ & 0.025 & 6 & $2.69 \pm 0.15^{* *}$ & 60.6 \\
\hline & 0.25 & 6 & $2.96 \pm 0.42^{* *}$ & 66.7 \\
\hline & 2.5 & 6 & $2.65 \pm 0.14^{* *}$ & 59.7 \\
\hline + Haloperidol & 0.05 & 6 & $4.30 \pm 0.24$ & 96.8 \\
\hline$+( \pm)$-Sulpiride & 100 & 6 & $4.11 \pm 0.10$ & 92.6 \\
\hline$+Y M 09151-2$ & 0.001 & 6 & $2.41 \pm 0.27^{* *}$ & 54.3 \\
\hline & 0.005 & 6 & $4.64 \pm 0.87$ & 104.5 \\
\hline
\end{tabular}

D-1 or D-2 receptor antagonist was administered $20 \mathrm{~min}$ prior to apomorphine (65 min before sacrifice). Each value represents the mean \pm S.E.M. DOPA levels after 3 -hydroxybenzylhydrazine treatment were $1.49 \pm 0.06 \mu \mathrm{g} / \mathrm{g}(\mathrm{N}=12) . \quad \mathrm{N}=$ number of experiments. ${ }^{* *} \mathrm{P}<0.01$, compared with the $\gamma$-butyrolactone control.

regulate the DA synthesis in the striatum are not D-1 but D-2 type. On the other hand, it has been reported that evoked-release of ${ }^{3} \mathrm{H}$-DA from the striatum in vitro is inhibited by D-2 receptor agonists, but not by a D-1 receptor agonist $(6,7)$ and suggested that the release-inhibiting DA autoreceptors are also the D-2 type.

Taking these results into consideration, the D-1 type of autoreceptors located on dopaminergic nerve terminals, if any, appears not to be involved in the regulation of DA synthesis. In our preliminary experiment, we have shown an involvement of postsynaptic D-1 receptors in the regulation mediated by the striato-nigral feedback loop of DA release from the striatum studied by the in vivo dialysis method $(\mathrm{H}$. Watanabe et al. unpublished observation). The functional role of D-1 receptors is not known, but the receptors seem to have some relation to the mobilization of a second messenger system including $A$ kinase through the activation of adenylate cyclase (21).

Acknowledgement: $W$ are indebted to Dr. A. Barnett (Schering Corp.) for the gift of SCH 23390 and to Dr. S. Usuda (Yamanouchi Seiyaku) for YM-09151-2.

\section{References}

1 Farnebo, L.O. and Hamberger, B.: Drug-induced changes in the release of ${ }^{3} \mathrm{H}$-monoamines from field stimulated rat brain slices. Acta Physiol. Scand. Supp. 371, 35-44 (1971)

2 Nowak, J.Z., Arbilla, S., Galzin, A.M. and Langer, S.Z.: Changes in sensitivity of release and modulating dopamine autoreceptors after chronic treatment with haloperidol. J. Pharmacol. Exp. Ther. 226, 558-564 (1983)

3 Bitran, M. and Bustos, G.: On the mechanism of presynaptic autoreceptor-mediated inhibition of transmitter synthesis in dopaminergic nerve terminals. Biochem. Pharmacol. 18, 2851-2860 (1982)

4 Kehr, W., Carlsson, A., Magnusson, T. and Atack, C.: Evidence for a receptor mediated feedback control of striatal tyrosine hydroxylase activity. J. Pharm. Pharmacol. 24, 744-747 (1972)

5 Roth, R.H., Walters, J.R. and Aghajanian, G.K.: Effect of impulse flow on the release and synthesis of dopamine in the rat striatum. In Frontiers in Catecholamine Research. Edited by Usdin. E. and Snyder. S.H., p. 567-574. Pergamon Press, inc., New York (1973)

6 Stoof, J.C., De Boer, T., Sminia, P. and Mulder, A.H.: Stimulation of $D_{2}$-dopamine receptors in rat neostriatum inhibits the release of acetylcholine and dopamine but does not affect the release of $\gamma$-aminobutyric acid, glutamate or serotonin. Eur. J. Pharmacol. 84, 211-214 (1982)

7 Lehman, J., Briley, M. and Langer, S.Z.: Characterization of dopamine autoreceptor and $\left({ }^{3} \mathrm{H}\right)$ spiperone binding sites in vitro with classical and novel dopamine receptor agonists. Eur. J. 
Pharmacol. 88, 11-26 (1983)

8 Stoof, J.C. and Kebabian, J.W.: Two dopamine receptors: biochemistry, physiology and pharmacology. Life Sci. 35, 2281-2296 (1984)

9 Wagner, J., Vitali, P., Palfreyman, M.G., Zraika, M. and Huot, S.: Simultaneous determination of 3,4-dihydroxyphenylalanine, 5-hydroxytryptophan, dopamine, 4-hydroxy-3-methoxyphenylalanine, norepinephrine. 3,4-dihydraxyphenylacetic acid, homovanillic acid, serotonin, 5hydroxyindoleacetic acid in rat CSF and brain by high performance liquid chromatography with electrochemical detection. J. Neurochem. 38, 1241-1254 (1982)

10 Watanabe, H.: Simple method for evaluation of stimulatory effect of drugs on presynaptic dopamine receptors in mice. J. Pharmacol. Methods 14, 41-47 (1985)

11 Duncan, D.B.: Multiple range and multiple $F$ tests. Biometrics 11, 1-25 (1955)

12 Setler, P.E., Sarau, H.M., Zirkle, C.L. and Saunders, H.L.: The central effects of a novel dopamine agonist. Eur. J. Pharmacol. 50, 419$430(1978)$

13 Onali, P., Mereu, G., Olianas, M.C., Bunse, P, Rosetti, Z. and Gessa, G.L.: SCH 23390, a selective D1 dopamine receptor blocker, enhances the firing rate of nigral dopaminergic neurons but fails to activate striatal tyrosine hydroxylase. Brain Res. 340, 1-7 (1985)

14 Galloway, M.P., Wolf, M.E. and Roth, R.H.: Regulation of dopamine synthesis in the medial prefrontal cortex is mediated by release modulating autoreceptors: Studies in vivo. J. Pharmacol. Exp. Ther. 236, 689-698 (1986)

15 Stoof, J.C. and Kebabian, J.W.: Opposing roles for the D-1 and the D-2 dopamine receptors in efflux of cyclic AMP from rat neostriatum. Nature 294, 366-368 (1981)

16 Terai, M., Usuda, S., Kuroiwa, I., Noshiro, O. and Maeno, $H .:$ Selective binding of $Y M-09151-2$, a new potent neuroleptic, to $\mathrm{d}-2$ dopaminergic receptors. Japan. J. Pharmacol. 33, 749-755 (1983)

17 Iorio, L.C., Barnett, A., Leitz, F.H., Houser, V.P. and Korduba, C.A.: SCH 23390, a potential benzazepine antipsychotic with unique interactions on dopaminergic systems. J. Pharmacol. Exp. Ther. 226, 462-468 (1983)

18 Hyttel, J.: SCH 23390-The first selective dopamine D.1 antagonist. Eur. J. Pharmacol. 91, 153-154 (1983)

19 Nagatsu, T.: Regulation of dopamine biosynthesis. Metabolism (Tokyo) 22, 99-110 (1985) (in Japanese)

20 Tissari, A.H., Rossetti, Z.L., Meloni, M., Frau, M.I. and Gessa, G.L.: Autoreceptors mediate the inhibition of dopamine synthesis by bromocriptine and lisuride in rats. Eur. J. Pharmacol. 91, 463-468 (1983)

21 Taylor, C.W. and Merritt, J.E.: Receptor coupling to polyphosphoinositide turnover: a parallel with the adenylate cyclase system. Trends Pharmacol. Sci. 7, 238-242 (1986) 